\title{
Economics as a Moral Science
}

\author{
By A. B. AtKinson \\ Nuffield College, Oxford \\ Final version received 10 March 2008.
}

\begin{abstract}
Economists frequently make judgments about economic welfare, but there is today little discussion of the foundations of welfare economics. It is assumed either that there is unanimity of interests, or that there is general acceptance of utilitarianism. This means that economics cannot address many key policy issues and that important differences in ethical views cannot be recognized. This paper argues that it is a legitimate exercise of economic analysis to examine the consequences of different ethical positions, taking case studies of employment as a macroeconomic objective, and the role of capabilities in the measurement of economic performance.
\end{abstract}

\section{INTRODUCTION}

Economics deals with ascertainable facts; ethics with valuations and obligations. The two fields of enquiry are not on the same plane of discourse. (Lionel Robbins, An Essay on the Nature and Significance of Economic Science, 1932, p. 132)

As against Robbins, Economics is essentially a moral science. That is to say, it employs introspection and judgement of value. (Lord Keynes, writing to Sir Roy Harrod, 4 July 1938)

These two quotations illustrate well the subject of this paper. The first is from Chapter VI of Robbins' An Essay on the Nature and Significance of Economic Science. The chapter opens with a totally justified criticism of the view that developments in modern Economic Theory furnish by themselves a set of norms capable of providing a basis for political practice' (p. 120), but goes on to argue for the complete separation of ethics and economics: as Robbins says, 'the two fields of enquiry are not on the same plane of discourse' (Robbins 1932, p. 132). With this, Keynes took issue. He argued that economics is essentially a moral science. ${ }^{1}$

If I have to choose between these two positions, then I would vote with Keynes. But the difference between them is in fact less stark than the two quotations suggest, and there is a lot of common ground. Indeed, in a later article in the Economic Journal, Robbins said that he was distressed if his Essay has suggested to the outside world 'a disunity among economists which I am persuaded does not exist' (1938, p. 640). Robbins is clearly right, in my view, in asserting that there are two different reasons why economists may disagree. We may disagree about the way in which we believe that the economy works; or we may disagree about the criteria to be applied in judging economic performance. A good example is provided by the $2 \%$ tax recently introduced in France on the sale of fish, with the proceeds used to compensate fishermen for the rise in the price of diesel. In the debate about this policy, people may object on the grounds that the tax will not have the intended effect: that the tax will be borne by the fishermen. Such a statement depends on how we view the determination of prices in the market and on the relative elasticities. (Incidentally, Robbins took the price elasticity of demand for herring as an example in another chapter of An Essay on the Nature and Significance of Economic Science.) This is a disagreement of the first kind. Or we may object to the policy on the grounds that there is no reason for giving priority to the compensation of fishermen. In 
the latter case, we are questioning the welfare criteria applied. It is a disagreement of the second kind.

Where I part company from Robbins is that I believe that questioning the welfare criteria is a legitimate part of economics. My position is in fact that adopted by Samuelson in his Foundations of Economic Analysis:

Robbins is undoubtedly correct. ... ethical conclusions cannot be derived in the same way that scientific hypotheses are inferred or verified. But it is not valid to conclude from this that there is no room [for] 'welfare economics'. It is a legitimate exercise of economic analysis to examine the consequences of various value judgments. (Samuelson 1947, p. 220)

The main thrust of this paper is that not only is welfare economics a legitimate exercise, but it is an exercise to which economists should devote more time and attention. Economics is a moral science. Welfare economics should be a central part of the discipline. But it is not. While welfare economics was a subject of importance half a century ago, today it has largely disappeared from the mainstream, and this is my starting point in Section I. Yet economists go on making welfare judgments, and Section II examines the-undiscussed-assumptions that underlie these welfare judgments. I then in Section III take two concrete examples of current policy issues where I believe that we can learn from an examination of the underlying welfare economics. Economics is not only a moral but also a very relevant science.

\section{The Strange DisApPeARANCE OF Welfare ECONOMICS ${ }^{2}$}

Even if Robbins felt that what he was saying was not controversial, his 'celebrated attack' on welfare economics, to use the phrase of Sen (1970), generated a strong response. The leading economic theorists of the day-Pigou, Harrod, Hicks, Kaldor, Lange, Samuelson and Scitovsky - all actively engaged in exploration of the foundations of welfare economics. The survey of 'welfare economics, 1939-1959' in the Economic Journal by Mishan (1960) referenced more than 60 articles on the theory of welfare criteria, with titles such as:

'Welfare propositions in economics' (Kaldor),

'The foundations of welfare economics' (Hicks, Lange and Little),

'Some aspects of welfare economics' (Pigou),

'Evaluation of real national income' (Samuelson).

There were important books on welfare economics by Little (1950), Baumol (1952) and Graaff (1957). These were all doctoral theses; welfare economics was the subject on which the best young scholars were working.

As it was put by Arrow and Scitovsky in their Introduction to Readings in Welfare Economics (1969): 'recently, welfare economics has greatly increased in importance. ... Economists want to know exactly what they are after, what is the meaning, the limitations, and the importance of economic efficiency and economic progress.' The Editorial Foreword to Winch's Analytical Welfare Economics (1971) claimed boldly that 'welfare economics is back in fashion'.

But the 1960s were the high water mark. From 1970, in fact all went quiet. Welfare economics was sidelined. Today there are relatively few journal articles on welfare criteria. For example, the 2006 volume of the Economic Journal contained, in the regular issues, some 46 articles totalling more than 1100 pages, but not one dealt with welfare 
criteria or the foundations of welfare judgments. There are few textbooks written on 'welfare economics'. Nor do many departments offer courses in welfare economics. In many places, Oxford included, welfare economics has been incorporated into microeconomics courses or into courses called 'general equilibrium and welfare economics'. Certainly that seems to be the case with textbooks. Indeed, in most microeconomics textbooks, welfare economics has been marginalized. According to Kreps, 'we will touch on the efficiency of various institutions, although this will be relatively deemphasised' (1990, p. 7). The widely used textbook by Varian in one edition (1993) described welfare economics as an 'optional extra'.

\section{Practice}

Welfare economics has largely disappeared from sight, a disappearance that is strange in the sense that economists have not ceased to make welfare statements. I should indeed stress that I am not asserting that economists have stopped offering policy advice, nor that they have stopped writing papers containing welfare propositions. Just taking the first 15 of the 46 articles in the 2006 Economic Journal, I found references to 'optimal community grants', 'efficient and inefficient equilibria', 'the social welfare consequences of indexation', 'the policy maker's loss function' and 'the welfare effects of regulatory adverse selection', each drawn from a different article. These articles are reaching clear normative conclusions: for example, in the last case 'legislation prohibiting the use of genetic tests for [life assurance] ratemaking may increase welfare' (Polborn et al. 2006, p. 327).

There is, moreover, a public demand for such normative statements. The central issues of global policy, such as climate change and world poverty, involve the setting of targets and the use of criteria to judge progress. To take the latter example, the World Bank regularly estimates the number of people living on less than $\$ 1$, or $\$ 2$, a day, as a means of monitoring progress towards the 2000 Millennium Development Goal of halving by 2015 the proportion of people living in extreme poverty. At a national level, in the United Kingdom the government is committed, following a historic announcement by Tony Blair in 1999, to the reduction of child poverty, the aim being to halve it by 2010 and its total eradication by 2020 .

Perhaps the most striking arena within which policy goals have been most debated is that of the European Union (EU). One of the little noted features of this new political organization is that forming common policy has required different member states to make explicit their objectives to a degree that was not previously the case. The formation of the EU has forced governments to agree on yardsticks to assess performance. What may have been taken for granted in national political debate has to be spelled out. A good example is provided by the 2000 Lisbon Agenda, which identified the EU primary goals as growth and employment, coupled with greater social inclusion. To these three pillars, an environmental dimension was subsequently added in June 2001 when a strategy for sustainable development was adopted by the EU. These four pillars form the central elements in the Shortlist of Structural Indicators now used to assess the performance of the EU.

The EU Structural Indicators, shown in Table 1, cover six domains: general economic background, employment, innovation and research, economic reform, social cohesion, and the environment. Contemplation of these indicators raises a number of questions, and they could do with critical examination. I return to those concerned with growth and employment in Section III, but for the present I want simply to make the point that there 
TABLE 1

EU STRUCTURAL INDicATORS

\begin{tabular}{lll}
\hline 1 & GDP per capita & Growth \\
2 & Labour productivity & Growth \\
3 & Employment rate 15-64 & Employment \\
4 & Employment rate of older workers 55-64 & Employment \\
5 & Youth educational attainment & Social inclusion \\
6 & R\&D spending, \% GDP & \\
7 & Comparative price levels & \\
8 & Investment spending, \% GDP & \\
9 At risk of poverty rate after social transfers & \\
10 Long-term unemployment rate & Social inclusion \\
11 Regional cohesion & Social inclusion \\
12 Greenhouse gas emissions & Social inclusion \\
13 Energy consumption & Sustainability \\
14 Inland freight volume & Sustainability \\
\hline & Sustainability \\
\hline
\end{tabular}

is a yawning gulf between, on the one hand, the policy world where objectives and targets are central to political discourse and, on the other hand, economic theory where there is very little discussion of what may underlie such performance criteria. In what follows, I want first (Section II) to tease out what is implicit in the welfare statements that economists do make today and then (Section III) to seek to demonstrate what we can learn from a deeper analysis of welfare criteria.

\section{What Underlies Welfare StATEMENTS TODAY?}

Academic journals are replete with welfare statements. Economists do not confine themselves to positive statements - determining elasticities and explaining mechanisms. They are making welfare judgments, such as the following:

'The optimal policy is ...'

'In this article, we examine the welfare consequences of ...'

'This change would increase social welfare.'

However, what is the underlying justification? From reading these and other propositions in the recent journal literature, I have formed the view that there are three main ways of interpreting what economists do.

\section{Representative agents}

The first approach is to assume away differences in all relevant economic interests. Many macroeconomic models are populated by identical households, often described as 'representative agents'. It is then assumed that changes in social welfare can be judged according to whether the representative household is better or worse off. I emphasize that it is a further assumption, since even if everyone were to be identical, there might be reasons why social judgments go beyond what enters individual utility. As is remarked by Samuelson, 'one does not have to be a John Donne ... to find fault with the above assumption' (1947, p. 224). For example, we may believe, as a society, that there are merits in a higher level of overall education. An educated society may be able to operate 
more effectively as a democracy. Such cases where we may override individual preferences have been described by Musgrave as 'merit goods'. I return to this concept later.

But, even if we stay within the framework of strictly individualistic welfare, we must certainly feel constrained by the assumption that everyone has the same interests. In most real-world policy decisions, there are conflicting interests. The assumption of a single representative agent may suffice for modelling macroeconomic behaviour (although even this is arguable - see Solow 2008), but it rules out most interesting welfare economic problems. If we just take the classic example, much used in the earlier welfare economic literature, of the reform of the Corn Laws, then at the heart of the political debate was the conflict between landlords and manufacturers, with the interests of the working class also coming into play. Today, the dividing lines may be rather different, but they exist and lie at the centre of many differences of opinion. For example, in the debate about labour market reform in Continental Europe, there are differing interests for workers in established jobs and those who are outsiders. It would not be possible to discuss the desirability of such reforms without recognizing these different interests. In the debate about pensions, there are conflicting interests of different generations.

This last example brings us indeed to an awkward question. What about the unavoidable fact that we were born at different dates? All members of a birth cohort may be identical, but their consumption will inevitably occur, at least in part, at different dates from that of their parents. The typical answer to this question is that intertemporal differences are subsumed in a dynastic utility function, which takes account of all future consumption. Better or worse off is judged according to the sum of future discounted utility for infinitely-lived dynasties. It is assumed that those present today take into account the interests of succeeding generations. Just to give one example, this approach is used by Lucas in his (1987) calculations of the cost of business cycles and in his (2003) Presidential Address to the American Economic Association.

This may be a logically satisfactory answer, but it is not one that is easy to explain to non-economists. Since there is often more than one adult generation of a dynasty, they may reasonably ask - whose dynastic welfare function? Are we saying to 50-year-olds that their welfare is judged by their 75-year-old parents? Or the reverse? If the reverse, when does the baton pass? The uneasiness surrounding this construction is apparent when we consider the issue of the rate at which future utility is discounted. (Note that I am talking here about the discount rate applied to utility, not to the rate at which future consumption is discounted, which takes account of differences in how well-off future generations will be.) The current dynastic head may apply quite a high rate of discount. Indeed, Lucas in his 1987 calculations uses a discount factor of 5\%, which means that the utility from consumption in 2025 is valued at under half today's utility. The appropriate rate of discount to apply is a subject of controversy, as has been evident from the debate following the Stern Report on Climate Change. Stern (2007) argues that, in terms of utility, only a very low rate of discount is justified. He works with $0.5 \%$, which implies that the utility from consumption in 2025 is valued almost as much (92\%) as today's utility. And Ramsey, in his original article on optimal savings, argued that any discounting is 'ethically indefensible' (1928, p. 543).

\section{Assumed agreement on a utilitarian welfare criterion}

The second approach does not assume away differences between people. There are different interests - of capitalists, workers and landlords, or of insiders and outsiders, or of rich and poor. But it is assumed instead that there is agreement on the welfare criterion

(C) The London School of Economics and Political Science 2009 
to be applied. Most economists today would, it is assumed, follow Robbins, who in 1938 said that 'my own attitude to problems of political action has always been one of what I may call provisional utilitarianism':

as a first approximation in handling questions relating to the lives and actions of large masses of people, the approach which counts each man as one, and, on that assumption, asks which way lies the greatest happiness, is less likely to lead one astray. (Robbins 1938, p. 635)

The Presidential Address of Lucas to the American Economic Association, given 65 years later, stated that:

To evaluate the effects of policy change on many different consumers, we can calculate welfare gains (perhaps losses, for some) for all of them, one at a time, and add the needed compensations to obtain the welfare gain for the group. (Lucas 2003, pp. 1-2)

Lucas appears to regard this statement as self-evident: he describes it as 'the general logic of quantitative welfare analysis'. However, this statement disregards the many objections that have been raised to this utilitarian approach. ${ }^{3}$ To begin with, we may not be content to add the welfare gains: the sum takes no account of how the utilities are distributed. As it was put by Sen, 'maximizing the sum of individual utilities is supremely unconcerned with the interpersonal distribution of that sum' (1973, p. 16). We may therefore want to consider more generally the Bergson-Samuelson individualist ${ }^{4}$ social welfare function $W\left[U_{1}, U_{2}, U_{3}, \ldots\right]$, and this does indeed appear widely in all areas of economics in which welfare judgments are made.

The more fundamental difficulty with this approach is that it does not take account of the fact that moral philosophy has moved on beyond utilitarianism, and fails to recognize that there are plurality and diversity in the welfare criteria that could be applied. Plurality refers here to the fact that a single person may bring to bear more than one set of welfare criteria. A person may, for example, be concerned with the greatest happiness, but also with personal liberty. To cite Robbins again, in 1977 he gave a lecture entitled 'Liberty and equality', both of which he recognized to be legitimate concerns. These two criteria may point in the same direction, but they may also conflict. Diversity refers to the fact that different people hold different sets of values. One person may be concerned with personal liberty and another with social justice. Where there are multiple welfare criteria, then it makes no sense to talk about the welfare consequences; instead we have to apply multiple criteria and consider how conflicts may be resolved.

In particular, welfare economics needs to take account of the alternatives to utilitarianism that have been advanced in the past half century, such as the theory of justice of Rawls (1971) and the concept of capabilities introduced by Sen (see, for example, Sen 1985). The theories they have advanced are complex and, in their application to economic policy problems, have been grossly simplified by economists, myself included. When the work of Rawls was first discussed by public finance economists in the early 1970s, we tended to pay more attention to his difference principle than to his first, and lexically prior, principle of basic liberties. The difference principle required that inequalities in a society should work to the greatest benefit of the least advantaged. This appealed to economists, since they could see the Rawlsian principle as a limiting case of giving more weight to those less well-off in a Bergson-Samuelson social welfare function. With, say, the function $W$ having a constant elasticity of substitution between individual welfares, the Rawlsian case was reached as the elasticity tended to zero. But this ignored the fact that Rawls was concerned with the distribution of what he 
called primary goods, rather than with the distribution of individual welfare. In the same way, Sen was concerned to change the evaluative space - in his case to the consideration of individual capabilities, which we may define broadly as the freedom that people have to function in key dimensions.

The question we need to put to Lucas, and indeed all those who refer to the welfare consequences, is how their conclusions would change if Bentham were replaced by Rawls or by Sen. Whatever one thinks of the merits of the views put forward in these two alternatives to utilitarianism, one has to ask - when making statements about public policy-how adoption of a different view from utilitarianism would affect the conclusions reached. Where people disagree about the desirability of a particular policy reform, is it possible that they do so because they are motivated by a different view of the objectives of society?

\section{Dominance}

This leads directly to the third approach, which is to seek conclusions that do not in fact change with changes in the welfare criteria: i.e. to seek to identify situations of dominance. The best known such approach is that based on Pareto dominance, where welfare statements are limited to changes that make everyone better off or at least no worse off. Such a change is described as a Pareto improvement - so $(100,201,500)$ beats $(100,200,400)$. A situation where there are no further possibilities for Pareto improvements is described as Pareto-efficient.

Paretian welfare economics has been popular. It is however only an incomplete ordering. Even a very modest loss for one person prevents us reaching any conclusion. As put by Sen, if preventing the burning of Rome would have made Emperor Nero feel worse off, then we cannot conclude that its burning was a mistake. He goes on to say that 'a society or an economy can be [Pareto-efficient] and still be perfectly disgusting' (1970, p. 22, where I have replaced Pareto-optimal by Pareto-efficient). Moreover, the Pareto approach is firmly based on individual welfares. As noted earlier, there may be reasons why social judgments may override individual welfares, as with the case of merit goods. These are non-welfarist considerations.

Even if we consider only individual welfares, however, we have to ask whether social welfare is always a non-decreasing function of individual welfare. Are there situations where we regard an improvement for one person as a worsening for society? The standard response is that this is simply envy, or 'spiteful egalitarianism' as it is called by Feldstein (2005) in his Presidential Address to the American Economic Association. But it is not evident that we can simply reject egalitarianism so easily. It has long had appeal. Plato argued that: "if a state is to avoid ... civil disintegration ... extreme poverty and wealth must not be allowed to rise in any section of the citizen-body, because both lead to disasters. This is why the legislator must announce now the acceptable limits of wealth and poverty' (quoted by Cowell 1977, p. 26). Plato's recommendation was that the limits be set at 4 to 1 . More recently, Tawney argued that 'a common culture ... is incompatible with the existence of sharp contrasts between the economic standards and educational opportunities of different classes. . . It involves, in short, a large measure of economic equality' (1964, p. 22).

There are therefore arguments for concern about distance, concerns that may be particularly relevant today in the UK as we observe a fanning out of the wage distribution at the top. If the median earnings in 2006 were about $£ 18,000$ a year, ${ }^{5}$ then the earnings of the top $1 \%$ start at some 5 times this amount. This exceeds the Platonic 
4:1. But it has not always been so: until 1991 the top $1 \%$ began at less than 4 times the median wage. The rise in top earnings began in the later 1970s, and was marked in the 1980s, but has continued strongly under New Labour. The top 1\% earned $41 / 4$ times median earnings when Labour came to power, and now earn approaching $51 / 4$ times. If this fanning out of the upper tail of the earnings distribution continues, then it will ultimately lead to the question being asked whether the distance has become unacceptably large. How big can the gap in earnings become before the contrasts come to be regarded as excessive?

\section{Conclusions}

In this section of the paper I have critically examined the approaches adopted by modern economists to welfare judgments. The key conclusions may be summarized in terms of a two-person diagram - see Figure 1. The first point is that if we assume that both are identical, located along the $45^{\circ}$ line, then welfare economics misses out most of the interesting policy issues - from the repeal of the Corn Laws to Global Warming. The policy problems with which we are typically faced are more like those shown by the possibility frontier. If we start inside the frontier, then improvements for both may be achievable, where we move outwards in a north-easterly direction. There may be scope for Pareto improvements. But once we reach the frontier, we have to trade gains for one person against losses for the other, and most actual policy changes involve some losers as well as some gainers. This means that a welfare judgment involves a stronger welfare criterion.

Most economists are at heart utilitarians, at least as revealed by their academic writings, leading to the choice of the point marked Bentham. The social welfare contours are straight lines with slope -1 . As noted above, there is nothing remotely egalitarian about the utilitarian position. The difference principle of Rawls, with its focus on the least advantaged (in the case shown, person 1), represents a contrast, and leads to different policy implications. In this case, the social welfare contours are at right angles centred on the line of equality - although we should note that the Rawlsian solution, too, is not necessarily egalitarian. The welfare of the less advantaged (person 1) is maximized, but - and I have drawn the frontier expressly for this reason - the maximum may fall short of the line of equality. This is a gross over-simplification of Rawls' theory of justice. Rawls was not concerned with individual utilities, but with primary goods. Sen too

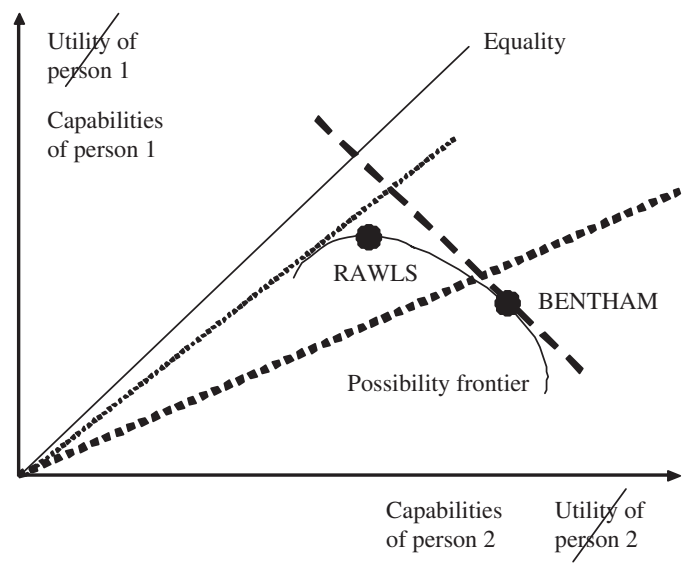

FIGURE 1. A diagrammatic representation of the issues. 
would strike out utilities, and, as shown in Figure 1, replace them by capabilities. I shall return to some of the implications later, in Section III.

Finally, we may reject welfarism in another sense, which is that social welfare may be concerned with distance and hence view negatively additions to the wellbeing of the rich if it takes them too far away from the rest of society. The application of a maximum ratio may, as shown by the heavy dotted line, restrict us to a cone around the line of equality. In the case shown, it would preclude the utilitarian solution. Indeed, it could, as indicated by the lighter dotted line, take us to the left of the Rawlsian position and indicate the choice of an allocation where both were worse off. As the diagram illustrates, there are important issues at stake.

\section{Why We NeED WeLFARE ECONOMICS}

So far, I have been critical of the absence of foundations for the welfare statements to be found in modern economics. In the last part of the paper, I want to be constructive, suggesting how welfare economics can be positively helpful. I have for this purpose taken two issues very relevant to current policy. They are drawn from the EU Structural Indicators cited earlier, but they have wider resonance.

\section{Employment as an objective}

I start with the choice of employment as an objective of policy. Why exactly is raising employment, for the whole working age population, or for older workers, an objective of EU policy? It should be stressed that we are concerned here with increasing employment, not with reducing unemployment. The argument for reducing unemployment is much more immediately compelling. Of course, raising employment may well lead to lower unemployment, but it need not do so. The employment rate can be raised by inducing people to stay in the labour force, or to re-enter the labour force. This indeed has been much of the thrust of government policy. Governments in the UK have been trying to end early retirement and to encourage greater participation in the labour force by the disabled and by lone parents.

But there is a prior question that has been little asked. Why do we want to increase employment rates? Why should we want a larger labour force? Here we need to distinguish several different arguments. The first - often advanced in an EU context - is that Europe's labour markets are heavily distorted and discourage work. People's decisions are being tilted against work. They are influenced by taxes and transfers, rather than by the real costs and benefits of working. A classic case is where one member of a couple is receiving an income-tested benefit, so that the partner has little financial incentive to work, since each $£ 1$ earned will reduce the transfer received. In this case, the aim is to better align the incentives faced by individuals: to level the playing field. The end is welfare improvement, and increased employment is a byproduct.

However, this is only part of the story. Governments appear to be concerned with more than the distortion of decisions, as is evidenced by the fact that they seem more interested in the total elasticity of labour supply than in the compensated elasticity relevant to welfare measures. Policy is directed not just at the fact that people's choices are tilted but at the actual choices they make. This is particularly apparent when we look at the older end of the age spectrum. When studies of early retirement refer to 'unused productive capacity', they are attaching a positive value to work, quite independently of how it is viewed by the worker. 
We have therefore to recognize that social decision criteria may be influenced by considerations other than individual welfare levels. Market employment may be an objective in its own right. One way of representing this is to say that employment is a 'merit good', like the more usual merits goods such as education or health care. It is of course important to note that it is market employment. If a person aged 63 gives up his or her job so as to look after the grandchildren, then this activity is not counted. Or, as is increasingly likely with four-generation families, the person aged 63 may be looking after their 90 -yearold parent. Adoption of the employment rate target tilts the decision away from caring towards staying in the labour force, possibly of course as a paid carer for someone else's parent. But this raises the question as to why unpaid work should not be counted.

There are of course possible answers, but we need to set them out. One such answer may be developed in terms of social exclusion. Here we may see a parallel between the literature on welfare economics and that on the measurement of poverty. The measurement of poverty in the UK has evolved, under the influence of the research of Townsend (1979) and of developments in Sweden and France, from a primary focus on financial resources to a broader concern with the capacity of individuals to participate in society. And we can trace the EU concern with employment back to just such a concern: the 1994 EU White Paper on Growth, Competitiveness, Employment argued that the creation of jobs was necessary to ensure that our children

be able to find hope and motivation in the prospect of participating in economic and social activity. (European Commission, 1994)

As it was put by Burchardt et al., an individual is socially excluded if he or she does not participate in key activities in the society in which he or she lives (Burchardt et al. 2002 , p. 30). Employment may quite reasonably be regarded as one of these 'key activities'.

The employment target may therefore be rationalized in terms of social integration; moreover, we can see why it is market work that is being prioritized. Making explicit such a rationale in my view serves two functions. First, in a democratic society, governments have to persuade members of the society of the legitimacy of the objectives, and the argument has to be made and tested. Second, it allows us to refine the resulting policy conclusions. For example, the socially inclusive nature of employment was justified in terms of young people, and one can see immediately the relevance to the banlieux of Paris, but the application to those aged 55-64 is less immediately apparent. And for young people, we can see that the degree to which employment promotes social integration depends on the quality of the jobs and the extent to which they do indeed offer future prospects.

The move from financial poverty to a broader concept of social exclusion has involved a move from a single-valued indicator to a multidimensional approach, and this, I would argue, is a key feature of moving outside the standard utilitarian welfare economics. In moving from Bentham to Rawls or Sen, we are changing not just the maximand but also the dimensionality. Rawls had a list of primary goods. Capabilities have a number of different domains: Nussbaum (2000), for example, lists ten. Set out schematically, we have a (blank) matrix of people and domains - see Table 2. The standard welfare economic approach is to assume that the domains are reduced to a single number representing individual welfare or utility, and the aggregation issue involves combining these into a single overall level of social welfare, as with the BergsonSamuelson social welfare function. 
TABLE 2

Different Forms of Aggregation

\begin{tabular}{lcr}
\hline & Domains & \\
\cline { 2 - 3 } Individuals Income & Employment & Education \\
\hline 1 & & \\
2 & & \\
\hline
\end{tabular}

This process may be contrasted with that implicitly adopted when formulating the employment objective. Here what we are doing is to aggregate for one domain across individuals: i.e. aggregating first vertically. This, however, misses the correlation across domains. We may reject the utility route, but be concerned about multiple deprivations. We may worry whether it is the same people who lose their jobs at 55 and who have low education and low income. The same applies to my second example, to which I now turn.

\section{Capability and the measurement of economic performance}

My second example also relates to the EU Structural Indicators, but it is of wider relevance. Indeed, it may be illustrated by reference to Australia. The 2006 OECD Survey of the Australian Economy concluded that 'living standards have steadily improved since the beginning of the 1990s' (OECD 2006, p. 3). The evidence cited, however, relates to the growth of national income. Growth in real gross domestic income had averaged over $4 \%$ in Australia. I am not questioning this figure, but what is debatable is the equation of the growth in national income (GDP for short) with improvement in living standards.

Here I am making not a purely semantic point, but rather one that goes to the heart of much economic debate. In a number of countries, there is increasing concern among economic policy-makers that we cannot take for granted that there is a direct connection between GDP and the living standards of households or individuals. Improvement in the macroeconomic numbers cannot be assumed to imply commensurate improvements in living standards across the population. As a result, politicians are rightly worried that success in securing economic growth, and raising the employment rate, has not been recognized by the population as a whole (or more crucially by the electorate as a whole). There is a sense among the citizens that their living standards have not risen. This is most obvious in the USA, where has been much questioning as to where the fruits of growth have gone, as ordinary people seem to be no better off than 10 or 20 years ago. In France, there is much concern about 'le pouvoir d'achat'. Yet in France GDP per capita has been rising: according to the IMF figures, real GDP per head at national prices in 2006 was nearly a fifth higher than in 1996. Even if the growth rate is less than in the past, and less than in the USA, it is still definitely positive, but this macroeconomic performance has not fed through into a sense of improved living standards.

This is causing a reconsideration of the basis for our economic assessment in terms of national accounts. National accounting is, I believe, one of the great social science success stories. The introduction of a systematic framework, broadly comparable across time and across countries, has transformed macroeconomic policy-making. At the same time, the foundations are rooted in a number of compromises. In fact, if one goes back to the origins of modern national accounting in the 1930s and 1940s, then one can see it as emanating from two different streams of economic thought. The first, and the most 
urgent in policy terms at the time, was the development of macroeconomic management. It was no accident that Keynes was a strong advocate. For this purpose, what was needed were consistent national aggregates - it was very much accounting. The second stream is the expression of the level of national welfare, stemming from the earlier welfare economic tradition developed by Pigou. The title of one of the articles cited earlier by Samuelson was the 'Evaluation of real national income', and this article was essentially concerned to provide a welfare economic underpinning to the numbers appearing in the national accounts.

At the time, it was clear that the marriage of these two sets of concerns was to some degree a marriage of convenience. The time has perhaps come for divorce. A number of people have come to the view that we need to construct new indicators of economic and social performance. And new indicators have already been constructed, of which I cite just one - the Human Development Index - chosen because it has been very much influenced by the capability approach. The HDI was introduced in 1990 under the aegis of Amartya Sen and Mahbub ul Haq of Pakistan, and continues in a more refined form to be published by the UN Development Programme in its annual Human Development Report. The HDI is a very reduced form of the capability approach; indeed, Sen has described it as a 'vulgar' measure. At the same time, he has noted that it is of the 'same level of crudeness as GNP' (Sen 1999, p. 318, n. 41). Moreover, it is a concrete implementation of an alternative approach to the underlying concept of wellbeing.

The HDI has three main domains, slightly different from those used before. Countries are ranked on each of these three domains. The UK ranks 18 th equal on life expectancy, 16th on education and 10th on GDP per capita. And then the domains are aggregated into the HDI. The UK is 16th overall, between Austria and Belgium. We are above Germany and below France. But what I am interested in is the procedure. What do capabilities bring to the party? Obviously they extend the dimensionality. This is perhaps the most important part, but the HDI also changes the way in which income is introduced. The index is based not on GDP per capita but on its logarithm. Why is this? According to the UNDP website, 'the HDI uses the logarithm of income, to reflect the diminishing importance of income with increasing GDP' (UNDP website, 2008). Or, as put when the index was first published, there are 'diminishing returns to transforming income into human capabilities' (UNDP 1990, p. 12).

But if there are diminishing returns, this applies at the individual level, not to the aggregate national income. This means that the appropriate procedure is not that used in the HDI but to take the logarithm of income at the individual level and then aggregate. In other words, we want to take not the logarithm of mean national income but the logarithm of the geometric mean. Unless all incomes are equal, the geometric mean is less than the arithmetic mean, reflecting the reduced rate at which income is transformed into capabilities as income rises. Taking the alternative approach seriously suggests, then, that we should assess economic performance by the geometric mean of incomes, ${ }^{6}$ not by the arithmetic mean as in the national accounts. This seems a very modest change, but it leads us to take a rather different view of recent growth performance, as is illustrated in Figure 2 for the case of the USA. As we know, overall household income has grown in the USA, particularly since 1990: from 1990 to 2006, the mean household income grew by a fifth. The geometric mean, on the other hand, grew more slowly. Over the period as a whole, it grew around $0.5 \%$ per annum more slowly than arithmetic mean income. This is a large amount: about equal to the difference in growth rate between the USA and the UK in the past decade. And in the most recent period, the geometric mean rose in the Clinton years and fell in the Bush years, leaving the 2006 figure scarcely higher than in 1990. 


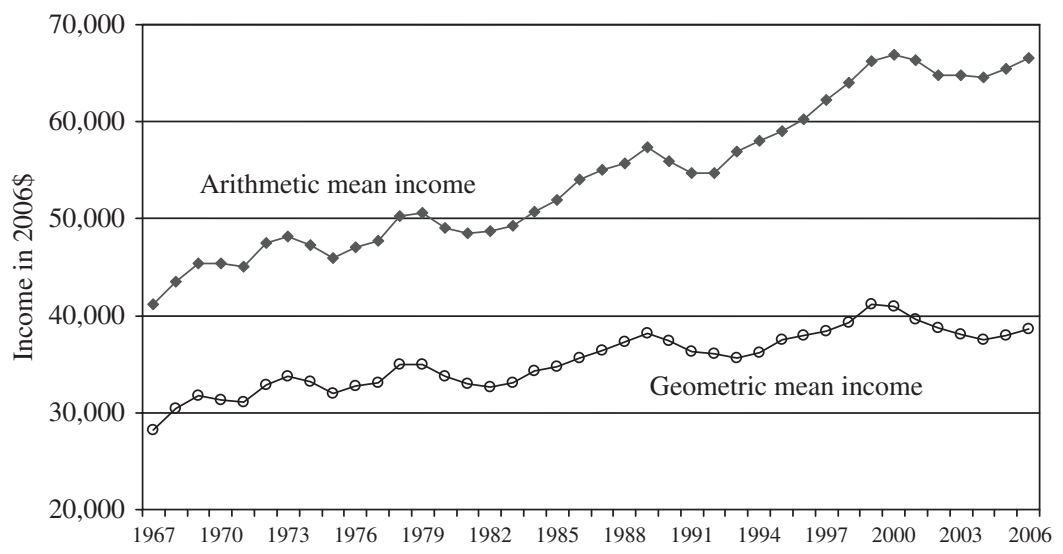

FIGURE 2. Two different perspectives of the growth of the US economy.

Source: US Census Bureau: Income, poverty, and health insurance coverage in the United States: 2006, Table A-3.

\section{CONCLUSIONS}

The findings just presented regarding the US economy may seem to justify the labelling of economics as 'the dismal science', but what I have tried to argue in this paper is that economics should be thought of as a moral science. Many of the ambiguities and disagreements stem not from differences of view about how the economy works but about the criteria to be applied when making judgments. The first conclusion to be stressed is that we cannot talk about the welfare consequences: there are several welfare criteria that could be applied in evaluating a change or a policy proposal. People can legitimately reach different conclusions because they apply different theories of justice. This may seem self-evident to non-economists, but the economics profession in recent years has tended either to assume away welfare judgments or to assume that there is general agreement.

The second conclusion is that examination of the foundations for welfare statements can help us think constructively, and extract new insights, about key policy issues today. Among the examples given are the growing distance between top earners and the rest, the EU objective of raising employment rates, the construction of the Human Development Index, and the measurement of national living standards. These are all matters that concern individual citizens and they should be centre stage in economics.

\section{ACKNOWLEDGMENTS}

This paper is a revised version of the inaugural Joseph Rowntree Foundation Lecture given at the University of York, January 2008, which in turn drew on material presented at the conference to mark the 75th anniversary of the publication of Lionel Robbins' An Essay on the Nature and Significance of Economic Science at the London School of Economics, 10-11 December 2007. I am grateful for the encouragement of Amos Witztum and Mozaffar Qizilbash, who invited me to give these lectures, and to the Joseph Rowntree Foundation for their support of the York lecture.

\section{NOTES}

1. I owe this quotation to Wright (1989, p. 473).

2. This is the title of an earlier article, Atkinson (2001), on which I have drawn in this section.

3. I am not entering here into the problems that arise with the aggregation of money measures of changes in individual welfare (see, for example, the review by Donaldson 1992). 
4. Following Graaff (1957, p. 9n), I insert the word 'individualist', because Bergson (1938) contemplated the case where the arguments of the social welfare function are not necessarily individual utilities; in most subsequent usage, this qualifier has been dropped.

5. These numbers are based on the Annual Survey of Hours and Earnings - see Atkinson and Voitchovsky (2008). The earnings refer to all full-time workers whose earnings were not affected by absence at the time of the survey.

6. As with a logarithmic social welfare function, converted back to an income equivalent.

\section{REFERENCES}

Arrow, K. J. and Scitovsky, T. (eds) (1969). Readings in Welfare Economics. London: Allen and Unwin.

Atkinson, A. B. (2001). The strange disappearance of welfare economics. Kyklos, 54, 193-206. - and Voitchovsky, S. (2008). The distribution of top earnings in the UK since the Second World War. Discussion paper.

BAumol, W. J. (1952). Welfare Economics and the Theory of the State. Cambridge, MA: Harvard University Press (2nd edn 1966).

Bergson, A. (1938). A reformulation of certain aspects of welfare economics. Quarterly Journal of Economics, 52, 310-14.

Burchardt, T., Le Grand, J. and Piachaud, D. (2002). Introduction. In J. Hills, J. Le Grand and D. Piachaud (eds), Understanding Social Exclusion. Oxford: Oxford University Press.

Cowell, F. A. (1977). Measuring Inequality. Deddington: Philip Allan.

DONALDSON, D. (1992). On the aggregation of money measures of well-being in applied welfare economics. Journal of Agricultural and Resource Economics, 17, 1-12.

European Commission (1994). White Paper on Growth, Competitiveness, Employment. Brussels: European Commission.

Feldstein, M. S. (2005). Rethinking social insurance. American Economic Review, 95, 1-24.

GraAFF, J. DE V. (1957). Theoretical Welfare Economics. Cambridge: Cambridge University Press.

KrePS, D. M. (1990). A Course in Microeconomic Theory. Princeton, NJ: Princeton University Press.

LitTle, I. M. D. (1950). A Critique of Welfare Economics. Oxford: Clarendon Press (2nd edn 1957).

LuCAS, R. E. (1987). Models of Business Cycles. Oxford: Basil Blackwell. (2003). Macroeconomic priorities. American Economic Review, 93, 1-14.

Mishan, E. J. (1960). A survey of welfare economics, 1939-1959. Economic Journal, 70, 197-265.

Nussbaum, M. (2000). Women and Human Development: The Capabilities Approach. Cambridge: Cambridge University Press.

OECD (2006). Survey of the Australian Economy. Paris: OECD.

Polborn, M. K., Hoy, M. and SAdanand, A. (2006). Advantageous effects of regulatory adverse selection in the life insurance market. Economic Journal, 116, 327-54.

RAMSEY, F. P. (1928). A mathematical theory of saving. Economic Journal, 38, 543-59.

Rawls, J. (1971). A Theory of Justice. Cambridge, MA: Harvard University Press.

RobBins, L. (1932). An Essay on the Nature and Significance of Economic Science. London: Allen and Unwin. (1938). Interpersonal comparisons of utility. Economic Journal, 48, 635-41.

(1977). Liberty and Equality. Occasional Paper 52. London: Institute of Economic Affairs.

SAmuelson, P. A. (1947). Foundations of Economic Analysis. Cambridge MA: Harvard University Press.

SEN, A. K. (1970). Collective Choice and Social Welfare. Edinburgh: Oliver and Boyd.

(1973). On Economic Inequality. Oxford: Clarendon Press.

(1985). Commodities and Capabilities. Amsterdam: North-Holland.

(1999). Development as Freedom. Oxford: Oxford University Press.

Solow, R. M. (2008). The state of macroeconomics. Journal of Economic Perspectives, 22(1), $243-6$.

Stern, N. H. (2007). The Economics of Climate Change. Cambridge: Cambridge University Press.

TAWNEY, R. H. (1964). Equality, new edn. London: Allen and Unwin.

Townsend, P. B. (1979). Poverty in the United Kingdom. London: Allen Lane.

United Nations Development Programme (UNDP) (1990). Human Development Report. Vienna: UNDP.

VARIAN, H. (1993). Intermediate Microeconomics, 3rd edn. New York: Norton.

Winch, D. (1971). Analytical Welfare Economics. London: Penguin Education.

Wright, R. (1989). Robbins as a political economist: a response to O'Brien. Economic Journal, 99, 471-8. 